\title{
Historic mussel beds (Mytilus edulis) in the sedimentary record of a back-barrier tidal flat near Spiekeroog Island, southern North Sea
}

Received: 27 February 2001 / Revised: 19 September 2001 / Accepted: 10 December 2001 / Published online: 22 March 2002 (C) Springer-Verlag and AWI 2002

\begin{abstract}
Mussel beds show irregular cycles of appearance, disappearance and reappearance at preferred distinct locations on intertidal flats. These cycles are documented in the depth profile by the presence of shell-rich sediments intercalated with sandy layers. Such mussel bed layers were regularly found over the past 12 years on the Swinnplate, a back-barrier tidal flat south of Spiekeroog Island, southern North Sea. They are characterised by the occurrence of sub-articulated pairs of Mytilus shells. Based on life span considerations, a period of at least 35-40 years over which mussel beds may have repeatedly established themselves is suggested. A survey in spring 2000 revealed a reduced occurrence of old, embedded beds on the Swinnplate. The present results, based on core profiles from 1992 to 2000 and amino acid age determination, show that alternations of shell layers indicative of former Mytilus beds and sediment layers provide insight into the historic development of tidal flat environments. The frequent occurrence of sub-articulated valve pairs in the shell layers documents that the embedding of the mussel beds took place soon after the death of the organisms without prior physical disturbance. Successions of historic Mytilus beds provide evidence that mussel beds are a regular, but not necessarily permanent, faunal feature of back-barrier tidal flats of the North Sea.
\end{abstract}

Keywords Mussel beds - Tidal flats - Mytilus . Sedimentary records $\cdot$ North Sea

Communicated by H. Asmus and R. Asmus

G. Hertweck (ब)

Senckenberg Institute, Schleusenstrasse 39A,

26382 Wilhelmshaven, Germany

e-mail: guenther.hertweck@sam.terramare.de

Tel.: +49-4421-947534, Fax: +49-04421-947550

G. Liebezeit

Research Centre Terramare, Schleusenstrasse 1, 26382 Wilhelmshaven, Germany

\section{Introduction}

The blue mussel, Mytilus edulis L., represents one of the most numerous organisms of the sessile epizoobenthos in the tidal environment of the southern North Sea. On tidal flats the mussels appear in various densities ranging from clusters of a few specimens, sparsely distributed on the sediment surface, to patches covering several square metres and, ultimately, to extensive areas of densely populated Mytilus beds. In the back-barrier area of Spiekeroog Island, East Frisian Wadden Sea, mussel beds covered about $10 \%$ of the total tidal flat surface between 1988 and 1993 (Hertweck 1995). Despite this low overall areal coverage the mussel beds, by their dark-coloured appearance and rugged relief, constitute the most conspicuous biological surface feature of the East Frisian tidal flats.

Most frequently, Mytilus beds occur on the central platforms of tidal flats, where larvae initially settle on tubes of the polychaete Lanice conchilega (Hertweck 1995) and dead shells or living specimens of the cockle Cerastoderma edule (Schäfer 1970; Wehrmann 1999). Colonisation of the bare sediment surface is also possible. The mussels then support themselves by mutual byssus-fixing (Wehrmann 1999). Formation of Mytilus beds in the marginal parts of tidal flats may also occur. In such cases, fixation occurs on shell accumulations in this zone, mostly originating from eroded former colonies of Mya arenaria.

Earlier field observations on the Swinnplate in the back-barrier area of Spiekeroog Island had shown that buried remains of Mytilus beds can often be found in sediment depths of up to $25 \mathrm{~cm}$. Therefore, it was of interest to typify the facies characteristics of the sediment column underlying living Mytilus beds with regard to particular features reflecting the former occurrence of mussel beds. This should provide insight into the relevant time scales and also information on the stability of the sediment and shell layers in tidal flat areas regularly colonised by Mytilus edulis.

Thus, the palaeontological aspect of Mytilus beds in this area was investigated from 1992 to 1996 within the 
scope of the Lower Saxonian Ecosystem Research Programme (Hertweck 1992, 1993a, b; Delafontaine 1993; Flemming and Delafontaine 1993, 1994; Hertweck and Liebezeit 1996; Kröncke 1996) to establish the history of this biotope. These investigations focused on facies development in the upper sediment column of tidal flat habitats typically colonised by $M$. edulis (Hertweck 1995, 1998).

While facies development studies in these tidal flats largely depend on identifiable remains of mussel beds, amino acid stratigraphy requires little sample material. It is, however, applicable only when the presence of a former mussel bed can be unambiguously established. The criterion used is the occurrence of sub-articulated shells, i.e. pairs of corresponding left and right valves close together, in the sediment layers of interest. Amino acid dating has been widely used both in terrestrial (e.g. Goodfriend 1987) and marine systems (e.g. Harada et al. 1997; Nyberg et al. 2001). In the present communication we therefore extend the palaeontological approach described above by samples taken from 1996 to 2000 using both relief casts and amino acid dating.

We are here, however, confronted with two different time scales. One relates to the observation of the age of living Mytilus individuals in a population while the other reflects the time periods when former Mytilus beds occurred in the area investigated and are now found as specific shell layers at defined sediment depths. Therefore, we will use the terms "individual age" and "chronological age" for the two different age aspects.

The chronological age determination of shell material makes use of the fact that the racemisation of amino acids which are present in the organic matrix of biogenic carbonates is controlled by two factors: time and temperature (Wehmiller 1984; Hare et al. 1997). Since the latter did not vary significantly in the investigation area over the last few hundred years, the change from the originally deposited amino acid L-form to a mixture of $\mathrm{D}$ - and L-forms is only time-dependent. After a suitable calibration, this allows the use of the extent of racemisation as a proxy for the chronological age of the shell material. Aspartic acid, as the fastest racemising compound, has been shown to be suitable for dating recent biogenic carbonates (e.g. Goodfriend 1992; Goodfriend et al. 1996).

\section{Study area}

The investigations were carried out in the East Frisian Wadden Sea, southern North Sea. This region represents an upper mesotidal environment (sensu Hayes 1979) characterised by barrier islands and extensive back-barrier tidal flats which are interrupted by a system of subtidal channels. The study area is situated south of the island of Spiekeroog (Fig. 1). Here, the tidal range is $2.7 \mathrm{~m}$ near the western part of the island and $2.9 \mathrm{~m}$ at the mainland. The tidal flat morphology is mainly controlled by tidal currents. In the main channel (Otzumer Balje), which extends from SE to NW, current velocities of $0.7-1.3 \mathrm{~m} / \mathrm{s}$ were measured (Bartholomä and Flemming 1993), whereas on the tidal flats $0.3 \mathrm{~m} / \mathrm{s}$ is a more typical value (Bartholomä 1993; Gehm et al. 2000). In addition, wave action plays an important role on the tidal flats adjacent to the main channel, especially those exposed to stormy winds from the western sector. Water temperature of the back-barrier area of Spiekeroog ranges between $1{ }^{\circ} \mathrm{C}$ in winter and $25^{\circ} \mathrm{C}$ in hot summers, as measured for 1994 and 1995 by Krögel (1997). The salinity of the back-barrier waters averages 31 PSU. However, peak values of 37 PSU have been measured within the first hour of the flooding tide (Gehm
Fig. 1 Map of the investigation area, the Swinnplate, in the back-barrier tidal flats of Spiekeroog Island, southern North Sea. Black areas represent distribution of Mytilus beds in the period 1988-1993. The bar indicates the sampling area from 1992 to 2000

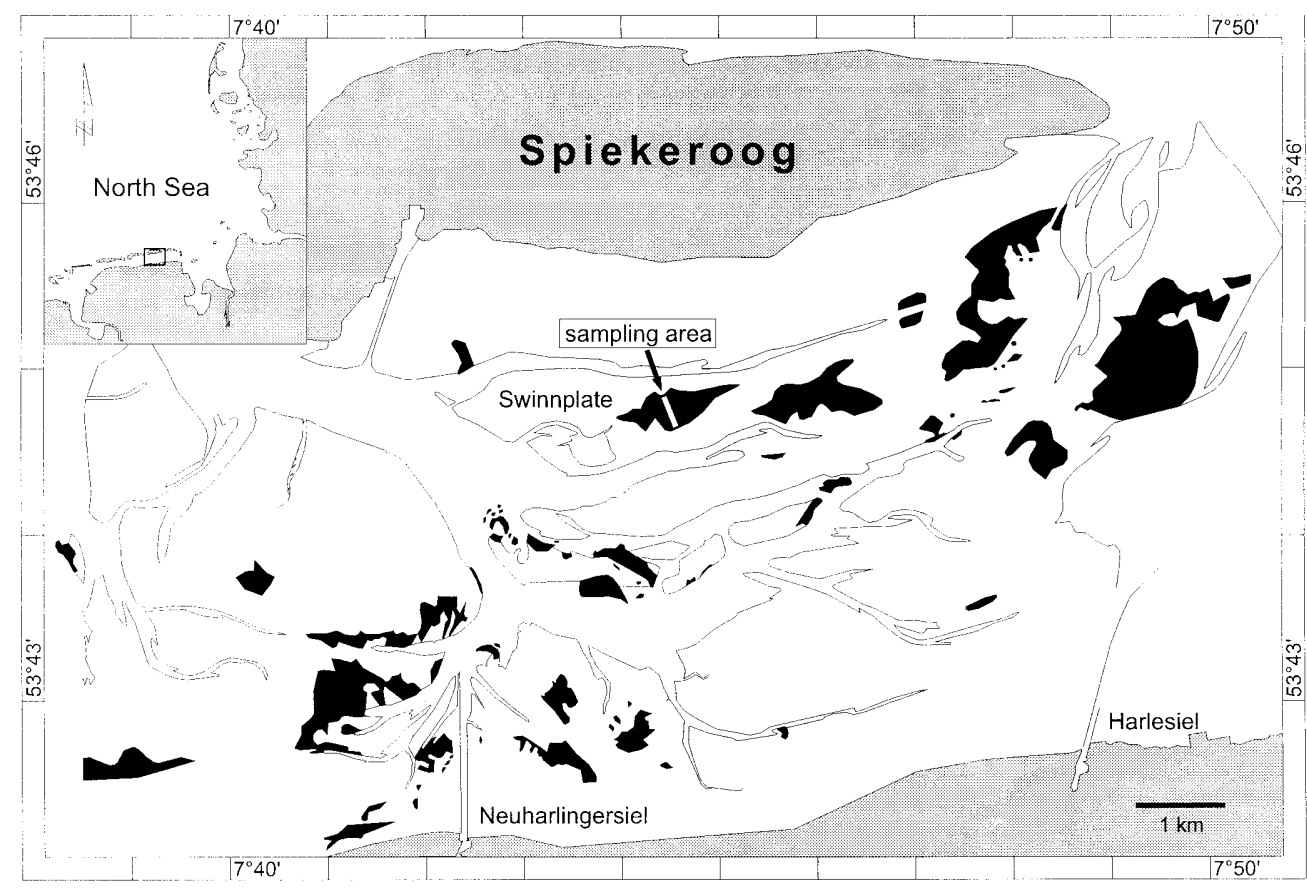


et al. 2000). The sediment distribution of the back-barrier tidal flats of Spiekeroog displays a coarsening succession from S to N (Ziegler 1989; Flemming and Ziegler 1995).

\section{Materials and methods}

\section{Sediment sampling}

In 1992 and 1994 sediments were sampled by box cores $(10 \times 18 \times$ $35 \mathrm{~cm}, \mathrm{w} \times 1 \times \mathrm{h})$ and in 1995 by tube cores $(100 \times 12 \mathrm{~cm}, 1 \times \varnothing)$. These were pushed manually into the sediment and then excavated. After transport to the laboratory and drying of the box cores and half of the tube cores at about $80-120^{\circ} \mathrm{C}$, durable Araldite relief casts were prepared as described by Reineck (1970).

In 1995 PVC tubes of $1 \mathrm{~m}$ length and $12 \mathrm{~cm}$ diameter were used. These were opened and cut into halves. One half was used for relief casts, the other for geochemical analyses. From this, shell material was removed manually and air-dried.

Sedimentary mussel layers are considered as historic beds when a high amount of sub-articulated Mytilus shells occurs in a defined shell layer. These shells have been embedded soon after death of the mussels without reworking processes causing separation of the Mytilus valve pairs.

\section{Age determination}

As pointed out above, temperature is a crucial factor in controlling amino acid D:L ratios. Shell material from the box cores taken in 1992 and 1994 was therefore not suitable for dating since the shells washed out of the relief casts had been heated up to $120^{\circ} \mathrm{C}$ during the hardening of the casts. Other shell material from these cores had been oven-dried at $80-90^{\circ} \mathrm{C}$. Shell samples from core MK4 taken in 1995, however, had been air-dried and were hence suitable for dating.

Cores SWP 2000/6(1) and SWP2000/6(2) were obtained in June 2000 at locations already sampled in 1992, 1994 and 1995. Shell samples from these cores were air-dried.

Shell samples were cleaned by scraping off adhering sediment. The remaining organic material was removed by treatment with ice-cold 30\% hydrogen peroxide solution. After removal of carbonate with ice-cold $2 \mathrm{M} \mathrm{HCl}$, the remaining organic matrix was centrifuged and washed several times with doubly distilled water. The pellet was transferred to a glass ampoule and $5 \mathrm{ml} 6 \mathrm{M} \mathrm{HCl}$ (Merck, suprapur) were added. After purging with nitrogen, the ampoules were sealed and heated at $110^{\circ} \mathrm{C}$ for $24 \mathrm{~h}$.

An aliquot of the hydrolysate was lyophilised and taken up in the same volume of $0.1 \mathrm{M}$ borate buffer, $\mathrm{pH}$ 9.5. HPLC separation of aspartic acid (ASP) enantiomers followed the method described by Fitznar et al. (1999) with modifications. Briefly, HPLC running conditions were adjusted for a rapid separation of aspartic acid only. All other derivatives were eluted as an unresolved group of compounds within $25 \mathrm{~min}$.
The age determination based on ASP D:L ratios has been described in detail by Behrends (1997). Briefly, Cerastoderma edule shells were calibrated against ${ }^{14} \mathrm{C}$ dates. For Mytilus edulis shells a similar racemisation rate is assumed. Behrends (1997) gives a relative error in age of $\pm 10 \%$ for C. edule. However, a comparison of Mya arenaria and $C$. edule rates gives an additional difference of about $10 \%$. As analytical reproducibility was $<2.6 \%$ the overall error, including possible differences in racemisation rates between C. edule and Mytilus edulis, is estimated to be about $\pm 30 \%$.

Kowalewski et al. (1998) found that D-alloisoleucine:L-isoleucine (D-allo-ILE:L-ILE) ratios might not be suitable for studying processes on time scales shorter than 1000 years. As aspartic acid racemisation is a much faster process, the uncertainty with this technique should be decades rather than centuries. Nevertheless, in the absence of a calibrated kinetic model, the estimated error given above should be borne in mind.

\section{Results}

Observations of the growth states of Mytilus edulis specimens in the living mussel bed of the Swinnplate provided insight into the development and repopulation phases in the time period from 1992 to 1996. In September 1992 two generations of living mussels showing mean shell lengths of $6.5 \mathrm{~cm}$ and $3.2 \mathrm{~cm}$, respectively, were present. The younger generation could be related to the spatfall of summer 1991 (see Hertweck and Liebezeit 1996). In July 1994 the Mytilus population of the Swinnplate displayed three generations with mean shell lengths of $7 \mathrm{~cm}, 5 \mathrm{~cm}$ and $0.9-1.3 \mathrm{~cm}$, respectively. The middle generation probably represents the younger one of 1992, i.e. it originated from the 1991 spatfall. The younger generation of 1994 related to a new spatfall in spring of the same year (Kröncke and Bergfeld 1997). Observations in August and October 1995 revealed that the remaining population of M. edulis corresponded to this last generation. The older generations were represented by dead shells only, having lengths between 5 and $7 \mathrm{~cm}$.

The sediment profile below the mussel bed observed in 1992 displayed two shell layers at sub-bottom levels of 6-9 $\mathrm{cm}$ and $14-17 \mathrm{~cm}$. These were mainly composed of Cerastoderma and Mytilus shells. Among the latter, sub-articulated shells, i.e. pairs of corresponding left and right valves close together, were frequent. This suggests that the mussels had been embedded soon after death and before disruption by a storm event. Above all, this points

Table 1 Core description MK 4

\begin{tabular}{|c|c|}
\hline $\begin{array}{l}\text { Above the } \\
\text { sediment surface }\end{array}$ & Mytilus bed, overgrown by Fucus vesiculosus \\
\hline $0-5 \mathrm{~cm}$ & $\begin{array}{l}\text { Shell layer in muddy/sandy matrix with shells of Cerastoderma edule and Mytilus edulis, Littorina littorea and few } \\
\text { Fucus remnants. Sediment matrix: silty fine sand, } 27.58 \% \text { mud }\end{array}$ \\
\hline $5-10 \mathrm{~cm}$ & Silty fine sand, $19.81 \%$ mud. Few sub-articulated Mytilus shells $(7 \mathrm{~cm})$ and Fucus remnants \\
\hline $10-16 \mathrm{~cm}$ & Fine sand with minor silt content, $9.81 \%$ mud, with few fine shell fragments; in places Lanice tubes \\
\hline $16-20 \mathrm{~cm}$ & Shell layer, with frequent single Mytilus valves \\
\hline $20-25 \mathrm{~cm}$ & Fine sand, slightly muddy with fine shell fragments and, in places, shell nests \\
\hline $25-38 \mathrm{~cm}$ & Dense layer of coarse shell debris (with fine sand matrix), predominantly C. edule \\
\hline $38-75 \mathrm{~cm}$ & $\begin{array}{l}\text { Silty fine sand, bioturbated. In } 48-56 \mathrm{~cm} \text { remnants of stratification. In } 53-65 \mathrm{~cm} \text { several bivalve shells } \\
\text { (predominantly } C \text {. edule, few } M . \text { edulis) }\end{array}$ \\
\hline 75-90 cm & Alternations of fine-sand and mud layers, mainly stratified, occasionally highly bioturbated; in places Mytilus shells \\
\hline
\end{tabular}


Fig. 2 Correlation of historic Mytilus beds in the sedimentary record of approximately the last 100 years. The chronological ages are estimated for the box cores from 1992 and 1994 (see text) and established by amino acid age determination for the cores from 1995 and 2000 . In the box cores from 2000 the upper of the two historic Mytilus beds has been eroded and replaced by younger deposits. The sediment surface was defined as the boundary between the living mussel beds in the year of sampling and the underlying deposits. Mussel bed ages are estimated (italics) or determined by amino acid dating

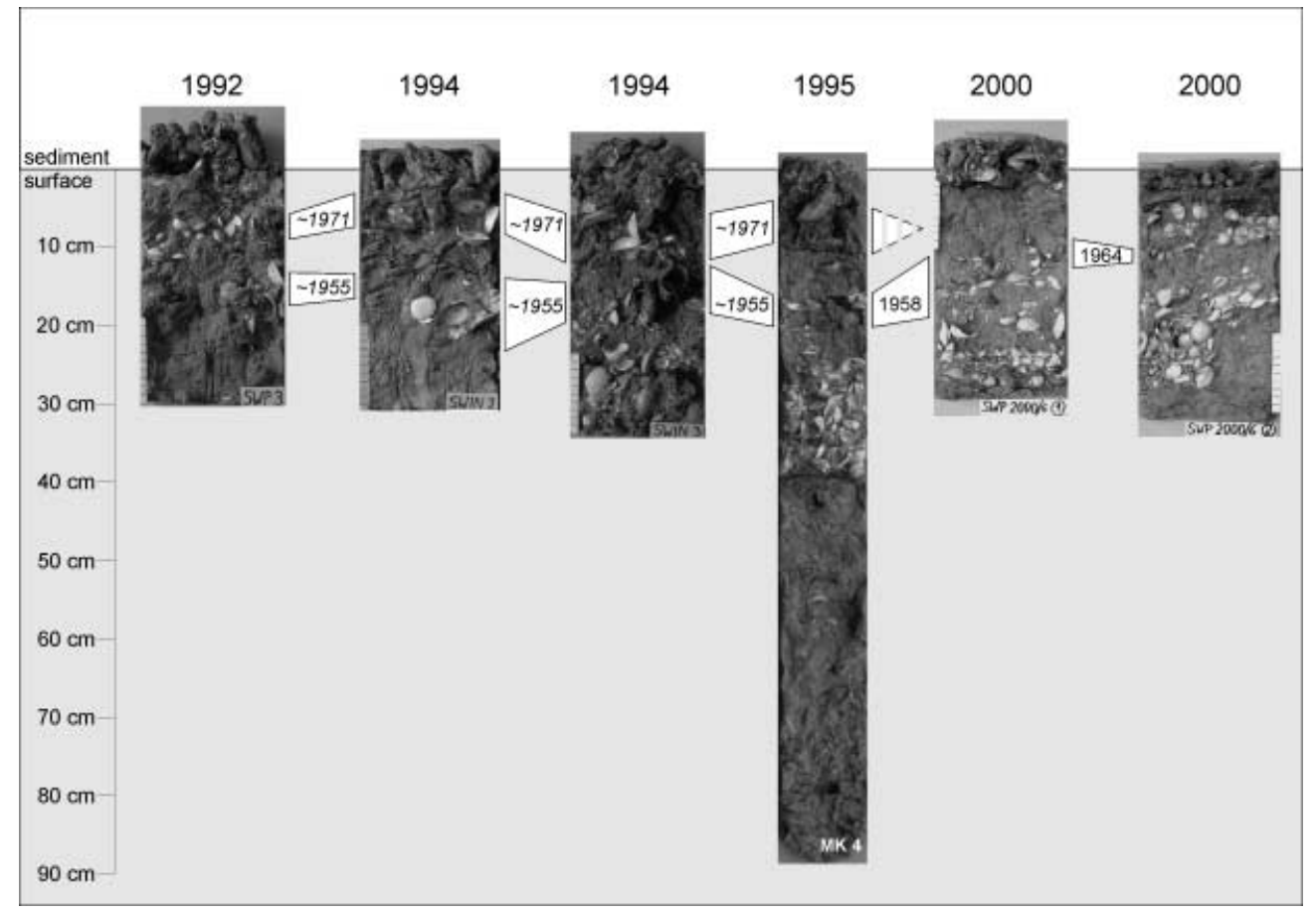

to the former existence of Mytilus beds at this site. Similarly structured shell layers were found at almost the same sub-bottom levels in sediment cores taken on the Swinnplate in 1994 and 1995 (Fig. 2).

In core MK4, taken in 1995, three distinct shell layers can be distinguished (Table 1). Mytilus shell samples from this core showed an increasing chronological age trend with depth (Fig. 3). Two exceptions at 25 and $80 \mathrm{~cm}$ might be due to the presence of reworked shells. In Fig. 3 the shells in the layer at $16-20 \mathrm{~cm}$ have a mean chronological age of 39 years before 1997. From this a net sediment accumulation rate of $34 \pm 7 \mathrm{~cm} / 100$ years can be calculated. This is in good agreement with the $35 \pm 4 \mathrm{~cm} / 100$ years obtained by Behrends (1997) for C. edule shells and the $25-30 \mathrm{~cm} / 100$ years given by e.g. Kunz (1993) from water gauge data. This sediment accumulation might be either due to concurrent adaptation to the rising sea-level or to the fact that the tidal basin watershed has shifted eastward over the last three centuries (Hohmeyer and Luck 1969). As, however, these aspects were not within the scope of our present investigation this problem was not considered further. It should also be pointed out that with the data at hand at best only a local approach to the problem can be made. A regional or even Wadden Sea-wide attempt to correlate aminostratigraphy with sea level rise would require a correspondingly comprehensive sample set.

The severe ice winter of 1995/96 caused the destruction of the whole Mytilus population on the Swinnplate. The extensive ice coverage, lasting 64 days in the backbarrier area of Spiekeroog Island (WSD 1997), led to a complete removal of the majority of mussel beds and associated fine-grained sediments (Kröncke and Bergfeld 1997). However, post-mortem mechanical destruction by

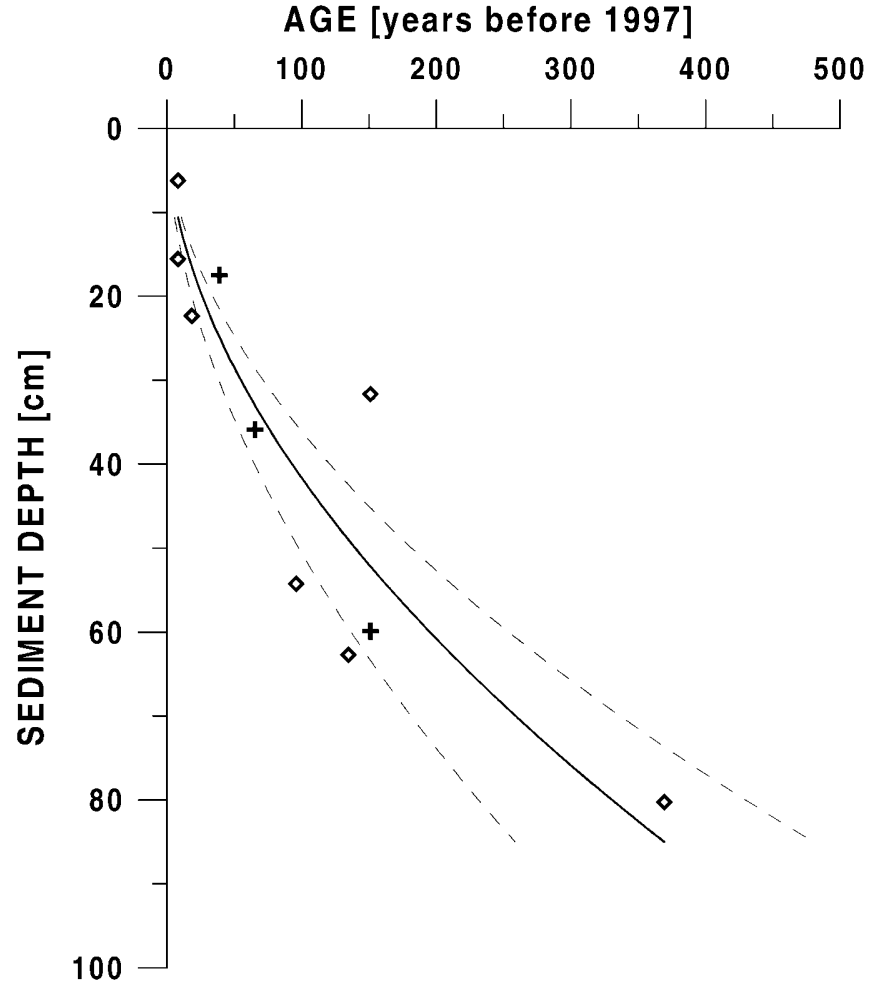

Fig. 3 Chronological age-depth distribution for Mytilus edulis shells in core MK 4. Diamonds data from Behrends (1997). Solid line $\log (z)=0.5168 * \log ($ age $)+1.4003, r^{2}=0.7854$; dashed line estimated $30 \%$ error in age determination

ice and/or storms did not occur in all parts of the tidal flats and the remains of one Mytilus colony were found at one locality. This colony still showed the original individual age structure, the sub-articulated shells displaying 
Table 2 Core description of SWP 2000/6 (1)

\begin{tabular}{ll}
$\begin{array}{l}\text { Above the } \\
\text { sediment surface }\end{array}$ & $\begin{array}{l}\text { Mytilus bed of medium age, shell length } 3.8-4.8 \mathrm{~cm} \text {; fixed on thin }(2-3 \mathrm{~cm}) \text { shell layer, mostly Cerastoderma edule, } \\
\text { some Mya arenaria valves. Spaces between individual mussels filled with biodepositional muddy sediment }\end{array}$ \\
\hline $0-10 \mathrm{~cm}$ & $\begin{array}{l}\text { Fine sand with low silt content; completely bioturbated, bioturbation of Scoloplos type. } 7-10 \mathrm{~cm} \text { : a restricted area } \\
\text { with Mytilus shells sticking upward from the deeper shell layer }\end{array}$ \\
$10-14 \mathrm{~cm}$ & $\begin{array}{l}\text { Shell layer. Upper main part: Mytilus shells, sub-articulated, originating from former Mytilus bed. At the base: } \\
\text { Horizontally deposited single valves of Mya areanaria (juv.), 1 Mytilus valve, convex side downward, }\end{array}$ \\
$14-22.5 \mathrm{~cm}$ & $\begin{array}{l}\text { 1 sub-articulated Macoma balthica } \\
\text { Fine sand with low silt content, completely bioturbated, in places embedded shells from C. edule and Mytilus edulis, } \\
\text { convex sides both upward and downward }\end{array}$ \\
$22.5-27 \mathrm{~cm}$ & $\begin{array}{l}\text { Shell layer, densely spaced, C. edule (mostly juv.), Mytilus edulis, Mya arenaria, Littorina littorea. Matrix fine sand } \\
\text { with low silt content. On top a medium-aged sub-articulated Mytilus shell }\end{array}$ \\
$27-29 \mathrm{~cm}$ & Fine sandy silt, completely bioturbated
\end{tabular}

Table 3 Core description of SWP 2000/6 (2)

\begin{tabular}{|c|c|}
\hline $0-5 \mathrm{~cm}$ & Fine sand with low silt content, horizontally bedded, slightly bioturbated. $0-3 \mathrm{~cm}$ : one Mytilus shell, both valves apart \\
\hline $5-10 \mathrm{~cm}$ & $\begin{array}{l}\text { Silty fine sand, completely bioturbated, with many juvenile (2nd year) Cerastoderma edule, sub-articulated and single } \\
\text { valves, showing a multitude of attachment disks from Mytilus byssal threads: indication of former Mytilus bed above } \\
\text { this layer, meanwhile eroded (the sub-articulated Mytilus shell in } 0-3 \mathrm{~cm} \text { as eventual remnant of the former Mytilus bed) }\end{array}$ \\
\hline $10-12 \mathrm{~cm}$ & Two sub-articulated Mytilus shells, horizontally embedded \\
\hline $10-15 \mathrm{~cm}$ & Silty fine sand, completely bioturbated \\
\hline $15-20 \mathrm{~cm}$ & $\begin{array}{l}\text { Dense shell layer with silty fine-sand matrix: Shells partly with convex side upward, partly densely spaced; mostly } \\
\text { C. edule, several Mytilus single valves, } 1 \text { subarticulated Mytilus shell (in } 15-17 \mathrm{~cm} \text { ). } 3 \text { Littorina littorea }\end{array}$ \\
\hline $20-25 \mathrm{~cm}$ & Silty fine sand, completely bioturbated \\
\hline $20-27 \mathrm{~cm}$ & $\begin{array}{l}\text { Part of the layer as densely spaced shell accumulation with C. edule, Mytilus edulis, Mya arenaria, Macoma balthica; } \\
\text { the adjacent area, laterally and below (down to the } 30 \mathrm{~cm} \text { level), silty fine sand, completely bioturbated }\end{array}$ \\
\hline $27-32 \mathrm{~cm}$ & Shell accumulation occupying a restricted area, with Hydrobia ulvae shells and small shell fragments \\
\hline $25-29 \mathrm{~cm}$ & Silty fine sand, bioturbated with still recognisable primary bedding \\
\hline $29-32 \mathrm{~cm}$ & Silty fine sand, horizontally bedded, slightly bioturbated \\
\hline
\end{tabular}

lengths of 5-6 cm, $4 \mathrm{~cm}$ and $2.8 \mathrm{~cm}$, respectively. This mussel bed assemblage was similar in its habitual character to the embedded shell layers found in the deeper sections of the sediment column.

In June 2000 a large part of the Swinnplate was again covered with mussel beds (Fig. 2) which originated from the 1996 spat fall. However, in deeper sediment layers the mussel bed remnants found in earlier surveys were not as prominent as before. A distinct Mytilus shell layer was found at 10-14 cm depth in core SWP 2000/6(1) (see Table 2), and remnants of such a layer also existed at 10-12 cm depth in core SWP 2000/6(2) (see Table 3). In the former, three sub-articulated Mytilus shells had post mortem ages of 8, 19 and 36 years before 2000 .

A living Mytilus bed was present at the top of the SWP 2000/6(1) profile, whereas living mussels were lacking in SWP 2000/6(2) which contained a Cerastoderma shell layer only at $5-10 \mathrm{~cm}$ depth (Fig. 2). These shells were covered with a multitude of attachment disks from the byssal threads of a former M. edulis population (Table 3). Nevertheless, one sub-articulated Mytilus shell was found in the sediment above the Cerastoderma layer.

\section{Discussion}

The length of the life period of the individual mussels in the remnants of former mussel beds embedded in the sediment column was estimated on the basis of several features characteristic of living Mytilus beds (see Hertweck and Liebezeit 1996; Hertweck 1998). According to field observations in the East Frisian tidal environment, the oldest generation of the living mussels observed on the Swinnplate in 1994 may have been 7 years old. Although individual ages of up to 12 years have been reported for blue mussels on oil platforms in the North Sea (Richardson et al. 1990), our field experience suggests maximum ages in the back-barrier tidal flats of about 7 years.

The two younger generations reflect subsequent colonisations in the 3rd and 6th year after the initial formation of the bed. As the maximum-sized Mytilus shells in the former mussel beds show lengths of $7 \mathrm{~cm}$, they also correspond to a life span of about 7 years. In this case, the numerical similarity of length and individual age is coincidental. Thus, the time span covered by the three consecutive periods of Mytilus populations may be estimated to be at least 21 years.

However, it is quite reasonable to assume a more extended timespan. In a sequence of mild winters the initial one and one or two subsequent mussel generations originating from regular colonisations may also have reached their maximum individual age, thus giving rise to a Mytilus bed occurence 10-13 years. On the other hand, unfavourable conditions during some of the years between such colonisation events may have prevented the formation of Mytilus beds. Therefore, the time period between the initial settlement of the oldest mussel bed pre- 
Fig. 4 Illustration of events leading to erosion of surface mussel beds in the Wadden Sea. Left effects of a severe ice winter, $a$ freezing of both living mussels and substratum and removal by ice drift, $b$ scraping of living Mytilus beds by icefloes. Right erosion and transport of surface sediments by storm surges also affecting deeper sediment layers with embedded historic Mytilus beds

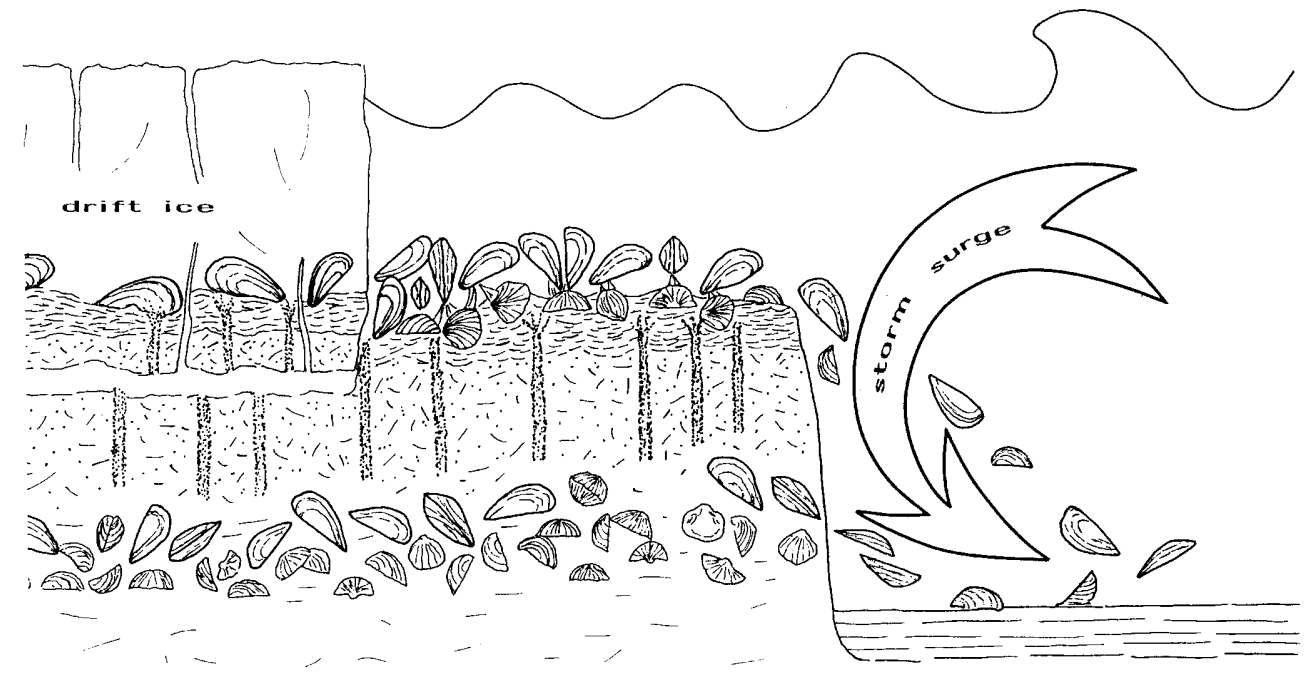

served in the sediment column of the Swinnplate to the youngest one may actually have been $35-40$ years (cf. Hertweck and Liebezeit 1996; Hertweck 1998). This estimate, made at the end of the Lower Saxonian Ecosystem Research Programme (Hertweck and Liebezeit 1996), is corroborated by the amino acid age determinations which, in core MK4, gave chronological ages of 39 years and, in SWP 2000/6(1), of 8-36 years. Given the relatively large error in amino acid age determination, which is due to the lack of independent calibration, the agreement between the estimates for the 1992-1994 samples and the aspartic acid D:L racemisation data is quite satisfactory.

The stratigraphic successions in the core profiles from the Swinnplate, as well as the determinations of chronological ages, reflect alternations between Mytilus beds present for several years and periods where Mytilus beds are lacking. Thus the results of our studies (cf. Hertweck and Liebezeit 1996) provide valuable insights into the history of this environment and its colonisation. In the present case several decades of development and variations in the faunal community structure of the tidal flat studied are evident, although in the cores taken in 2000 the uppermost of the two historic and hence second youngest colonisation period is lacking. However, the presence of the oldest beds implies that the causative agents do not affect the deeper sediment column, thus also suggesting a certain degree of sediment stability in the central parts of the tidal flats.

The isolated occurrence of a dead Mytilus colony on the tidal flat surface after the ice winter of 1995/96 suggests that in intertidal environments the embedding of such post mortem remnants of faunal communities requires special conditions. Thus, preservation as recognisable mussel bed remnants in the stratigraphic record is most probably the exception rather than the rule. Normally, mussel beds undergo a gradual deterioration process resulting in the production of dead, but still articulated, shells which will soon be separated by decay of the ligament. Subsequently, the Mytilus valves are subject to reworking and locally limited transport by wave action and currents. In this way, articulated dead Mytilus shells occur only sporadically in living Mytilus beds, as demonstrated by Wehrmann (2002).

Besides storms, severe winters with extensive ice coverage of the tidal flats may also be causative for the more or less complete erosion of living or dead Mytilus beds (Fig. 4). Thus, their preservation in the sedimentary record as documented by layers of sub-articulated shells appears to be related to periods with mild winters and little storm activity. On the other hand, favourable weather conditions over a period of several years may result in multi-generational Mytilus beds with a life span of about 10-13 years. This can be taken as an approximate measure for the estimation of life periods of historic mussel beds in the sedimentary record. The remnants of historic Mytilus beds preserved in the sedimentary record therefore allow a realistic reconstruction of Mytilus bed formation on tidal flats. As known from long-term biological surveys on East Frisian tidal flats (Obert and Michaelis 1991; Michaelis 1993; Millat and Herlyn 1999; Herlyn and Millat 2000), Mytilus beds undergo considerable changes in terms of temporal fluctuation and patchiness on different scales. Fluctuation would encompass not only presence or absence, but also deterioration and recolonisation processes. Unfavourable weather conditions, predation, pollution and disturbance by fishery may also play their part in determining the presence or absence of mussel beds. Thus, premature statements about the ecological breakdown of mussel beds may arise when these processes are not taken into account. Such processes are also reflected by the sedimentary record. By applying amino acid age determination to embedded shell layers, the occurrence of Mytilus beds can be traced back into the past. Their repeated occurrence over long time periods demonstrates that Mytilus beds are a regular but not necessarily permanent faunal feature of North Sea tidal flats. 


\section{Conclusions}

The results presented above show that alternations of historic Mytilus beds rich in sub-articulated shells and shell-free sediment layers provide insight into the development of tidal flat environments.

Such alternations point to repeated colonisation and post mortem embedding of Mytilus beds and intermittent periods where mussel beds are lacking. Amino acid dating allows us to relate this variability to a temporal framework, thus enabling a more quantitative assessment of the historic development.

Stratigraphic successions with intercalations of historic Mytilus beds, as found in the Spiekeroog tidal flats, show that mussel beds are a regular but not necessarily permanent faunal feature of back-barrier tidal flats in the North Sea.

Acknowledgements We are indebted to Achim Wehrmann and Ingrid Kröncke for numerous fruitful discussions and to two anonymous reviewers for helpful comments that improved the manuscript. Figures 1 and 2 were expertly drawn by Achim Wehrmann, Fig. 4 by Renate Flügel. This work was partly financed by the Bundesministerium für Bildung und Wissenschaft under contract No. 03F0112A.

\section{References}

Bartholomä A (1993) Zeitliche Variabilität und räumliche Inhomogenität in den Substrateigenschaften und der Zoobenthosbesiedlung im Umfeld von Miesmuschelbänken. D. Hydrodynamik. Ber Senckenb aM 93/1:117-123

Bartholomä A, Flemming BW (1993) Zeitliche Variabilität in den Sedimentparametern und der Morphologie auf der Gröninger Plate (Spiekerooger Watt). Ber Senckenb aM 93/1:54-48

Behrends B (1997) Aminosäuren in Sedimenten und Partikeln des Wattenmeeres. PhD thesis, Oldenburg University, Germany

Delafontaine M (1993) Zeitliche Variabilität und räumliche Inhomogenität in den Substrateigenschaften und der Zoobenthosbesiedlung im Umfeld von Miesmuschelbänken. B. Aspects of a shell budget: production, burial and interspecific competition. Ber Senckenb aM 93/1:64-98

Flemming BW, Delafontaine MT (1993) Zeitliche Variabilität und räumliche Inhomogenität in den Substrateigenschaften und der Zoobenthosbesiedlung im Umfeld von Miesmuschelbänken. C. Morphodynamik und Biodeposition. Ber Senckenb aM 93/1:99-116

Flemming BW, Delafontaine MT (1994) Biodeposition in a juvenile mussel bed of the East Frisian Wadden Sea (southern North Sea). Neth J Aquat Ecol 28:289-297

Fitznar HP, Lobbes JM, Kattner G (1999) Determination of enantiomeric amino acids with high-performance liquid chromatography and pre-column derivatisation with o-phthaldialdehyde and $\mathrm{N}$-isobutyrylcysteine in seawater and fossil samples (mollusks). J Chromatogr A 832:123-132

Flemming BW, Ziegler K (1995) High-resolution grain size distribution patterns and textural trends in the back-barrier environment of Spiekeroog Island (southern North Sea). Senckenb Marit 26:1-24

Gehm G, Wilken M, Liebezeit G (2000) Temporal and spatial high resolution analysis of nutrient dynamics in the near bottom layer of the Wadden Sea: methodological aspects and first results. Senckenb Marit 30:105-114

Goodfriend GA (1987) Chronostratigraphic studies of sediments in the Negev desert, using amino acid epimerization analysis of land snail shells. Quat Res 28:374-392
Goodfriend GA (1992) Rapid racemization of aspartic acid in mollusc shells and potential for dating over recent centuries. Nature 357:399-401

Goodfriend GA, Brigham-Grette J, Miller GH (1996) Enhanced age resolution of the marine Quaternary record in the Arctic using aspartic acid racemization dating of bivalve shells. Quat Res 45:176-187

Harada N, Handa N, Oba T, Matsuoka H, Kimoto K, Kusakabe M (1997) Age determination of marine sediments in the western North Pacific by aspartic acid chronology. J Oceanogr 53:1-7

Hare PE, Endt DW von, Kokis JE (1997) Protein and amino acid diagenesis dating. In: Taylor JE, Aitken JC (eds) Chronometric dating in archaeology. Plenum, New York, pp 261-296

Hayes MO (1979) Barrier island morphology as a function of tidal and wave regime. In: Leatherman SP (ed) Barrier islands from the Gulf of St Lawrence to the Gulf of Mexico. Academic Press, New York, pp 1-27

Herlyn M, Millat G (2000) Decline of the intertidal blue mussel (Mytilus edulis) stock at the coast of Lower Saxony (Wadden Sea) and influence of mussel fishery on the development of young mussel beds. Hydrobiologia 426:203-210

Hertweck G (1992) Distribution pattern of benthos and lebensspuren in the Spiekeroog back barrier tidal flat area (southern North Sea). In: Flemming BW (ed) Tidal clastics 92: Third International Research Symposium on Modern and Ancient Clastic Tidal Deposits/Sixth International Senckenberg Conference. (Abstract vol, Courier Forschungsinstitut Senckenberg 151) Senckenberg Institute, Wilhelmshaven, Germany, pp 40-42

Hertweck G (1993a) Zeitliche Variabilität und räumliche Inhomogenität in den Substrateigenschaften und der Zoobenthosbesiedlung im Umfeld von Miesmuschelbänken. A. Biofazies und Aktuopaläontologie. Ber Senckenb aM 93/1:49-63

Hertweck G (1993b) Faziesentwicklung im biosedimentären System Mytilus-Bank. Sediment 93, 8 Sedimentologen-Treffen Marburg 1993. (Abstract vol) Geologica et Palaeontologica, Marburg, Germany, pp 44-45

Hertweck G (1995) Verteilung charakteristischer Sedimentkörper und Benthossiedlungen im Rückseitenwatt der Insel Spiekeroog, südliche Nordsee. I. Ergebnisse der Wattkartierung 1988-89. Senckenb Marit 26:81-94

Hertweck G (1998) Facies characteristics of back-barrier tidal flats of the East Frisian island of Spiekeroog, southern North Sea. In: Alexander CR, Davis RA, Henry VJ (eds) Tidalites: processes and products. (SEPM special publication 61) Society for Sedimentary Geology, Albuquerque, N.M. pp 23-30

Hertweck G, Liebezeit G (1996) Biogenic and geochemical properties of intertidal biosedimentary deposits related to Mytilus beds. In: Dworschak PC, Stachowitsch M, Ott JA (eds) Influences of organisms on their environment: the role of episodic events. Proceedings of the 29th European Marine Biology Symposium 1994, Vienna. (Pubblicazioni della Stazione Zoologica di Napoli: Marine Ecology 17) Blackwell, Vienna, pp 131-144

Hohmeyer H, Luck G (1969) Das historische Kartenwerk 1:50 000 der niedersächsischen Wasserwirtschaftsverwaltung als Ergebnis historisch-topographischer Untersuchungen und Grundlage zur kausalen Deutung der Hydrovorgänge im Küstengebiet. Veroeff Nds Inst Landeskd, Landesd- Volkskd, I. Natur, Wirtschaft, Siedlung Planung 93:1-36

Kowalewski M, Goodfriend GA, Flessa KW (1998) High-resolution estimates of temporal mixing within shell beds: the evils and virtues of time-averaging. Paleobiology 24:287-304

Krögel F (1997) Einfluß von Viskosität und Dichte des Seewassers auf Transport und Ablagerung von Wattsedimenten (Langeooger Rückseitenwatt, Südliche Nordsee). Ber Fachber Geowiss Univ Bremen 102:1-169

Kröncke I (1996) Impact of biodeposition on macrofaunal communities in intertidal sandflats. In: Dworschak PC, Stachowitsch M, Ott JA (eds) Influences of organisms on their environment: the role of episodic events. Proceedings of the 29th European Marine Biology Symposium 1994, Vienna. (Pubblicazioni della Stazione Zoologica di Napoli: Marine Ecology 17) Blackwell, Vienna, pp 159-174 
Kröncke I, Bergfeld C (1997) Makrofaunauntersuchungen auf der Swinnplate. In: Flemming BW, et al (eds) Zur Elastizität makrofaunistischer biosedimentärer Systeme in Spiekerooger Watt: Wechselwirkungen zwischen Organismen, Sediment und Wasserkörper. Ökosystemforschung Niedersächsisches Wattenmeer ELAWAT. Abschlussbericht Teilvorhaben B6, pp $117-$ 152

Kunz H (1993) Klimaänderung und ihre Folgen für Wasserhaushalt, Gewässernutzung und Gewässerschutz. In: Schellnhuber H-J, Sterr H (eds) Klimaänderung und Küste. Springer, Berlin Heidelberg New York, pp 97-136

Michaelis H (1993) Miesmuschelbestände der Niedersächsischen Watten. Rep Niedersächs Landesamt Ökol Forschungsstelle Küste Norderney, Germany

Millat G, Herlyn M (1999) Documentation of intertidal mussel bed (Mytilus edulis) sites at the coast of Lower Saxony. Senckenb Marit 29 [Suppl]:83-89

Nyberg J, Csapo J, Malmgren BA, Winter A (2001) Changes in the D- and L-content of aspartic acid, glutamic acid, and alanine in a scleractinian coral over the last 300 years. Org Geochem 32:623-632

Obert B, Michaelis H (1991) History and ecology of the mussel beds (Mytilus edulis L.) in a catchment of a Wadden Sea tidal inlet. In: Elliot M, Ducrotoy JP (eds) Estuaries and coasts: spatial and temporal intercomparisons. Olsen and Olsen, Copenhagen, pp 185-194
Reineck H-E (1970) Reliefguss und projizierbarer Dickschliff. Senckenb Marit 2:61-66

Richardson CA, Seed R; Naylor E (1990) Use of internal growth bands for measuring individual and population growth rates in Mytilus edulis from offshore production platforms. Mar Ecol Prog Ser 66:259-265

Schäfer W (1970) Aktuopaläontologische Beobachtungen. 9. Faunenwechsel. Senckenb Marit 2:85-101

Wehmiller JF (1984) Relative and absolute dating of Quaternary mollusks with amino acid racemization: evaluation, applications and questions. In: Mahaney WC (ed) Quaternary dating methods. Elsevier, Amsterdam, pp 171-193

Wehrmann A (1999) Long-term survival of epibenthic Cerastoderma edule (L.) in bivalve clusters on backbarrier tidal faults, North Sea. Senckenb Marit 30:47-61

Wehrmann A (2002) Are mussel beds just mussel beds? The persistence of epibenthic cockles (Cerastoderma edule) in 'mussel beds' of North Sea back-barrier tidal flats and its importance for taphonomic interpretations in paleoecology. Helgol Mar Res

WSD Wasser- und Schiffahrtsdirektion Nordwest (1997) Eisangaben für die Pegel im Bereich der WSD Nordwest, Winter 1995/96 und 96/97. Anlage zu den Jahresberichten T3-221.3/1

Ziegler K (1989) Holozäne Entwicklung, Aktuogeologie und Sedimentdynamik des Spiekerooger Rückseitenwattes. Dipl-Arb, Technische Universität Clausthal, Germany 